\title{
Pyramidal Ownership and Company Value: Evidence from Polish Listed Companies
}

Maria Aluchna' and Tomasz Kuszewski²

ABSTRACT

\begin{abstract}
This paper examines the effects of pyramidal ownership. Using the sample of 162 non-financial companies listed on the Warsaw Stock Exchange during the period 2010-2014, we verify the relation between the adoption of a pyramidal structure and company value. Specifically, we show that the link between pyramidal ownership and company value is more complex than previously thought addressing the aspect of ownership concentration and dual class shares. Our results indicate that the use of pyramids is associated with a higher value measured by Tobin's Q, supporting the efficient monitoring hypothesis. Contrary to our expectations the combination of pyramidal ownership and dual class shares is correlated with lower Q. Finally, while the adoption of a pyramid by a majority shareholder does not impact firm value, the combination of a pyramid, ownership concentration and dual class shares is associated with higher $\mathrm{Q}$. This finding suggests that the blockholder ownership outweighs the possible cost of excessive disproportionate ownership and that pyramids and dual class shares have different effects on company value.
\end{abstract}

KEY WORDS: $\quad$ Pyramidal ownership, pyramidal structures, Poland.

JEL Classification: M21, L25.

SGH Warsaw School of Economics, Department of Management Theory, Poland'

University of Economics and Human Sciences in Warsaw, Poland ${ }^{2}$

\section{Introduction}

The existing literature associates the emergence of pyramids with a number of drivers, such as risk diversification (Almeida \& Wolfenzon, 2006), the prospects of establishing new ventures and the potential for business development by successful entrepreneurs (Almeida et al., 2011), tax optimization (Morck, 2005), and separating cash flow and control rights (Villalonga \& Amit, 2008). Recent studies raise questions on these relationships and suggest that the motivations and effects of pyramidal ownership are more complex than initially expected.

Despite numerous studies there is still no theoretical or empirical consensus on the use of pyramidal

Correspondence concerning this article should be addressed to: Maria Aluchna, Department of Management Theory, SGH Warsaw School of Economics, al. Niepodleglości 162, 02-554, Warsaw, Poland. E-mail:a.maria.aluchna@sgh.waw.pl structure and its effect on company value. Prior research originates from two alternative notions on monitoring and expropriation of concentrated control. The expropriation effects are driven by the existence of agency costs identified in leverage control settings which lead to a wedge between control rights and cash flow rights (Su, 2015). Numerous studies indicate the downsides of pyramidal ownership (Riyanto \& Toolsema, 2008), reflected in the expropriation of minority investors by dominant shareholders, who may engage in related party transactions to extract private benefits. As a consequence, research indicates the negative influence of the divergence between the cash flow rights and control rights on firm value, usually measured by Tobin's Q or its approximation (Baek et al., 2004; Boubaker, 2007; Bozec et al., 2010; Villalonga \& Amit, 2008). These problems are exacerbated in the context of weak institutional 
environments and insufficient investor protection. The alternative view offers the monitoring premise assuming high cash flow ownership of the largest investors motivates them to maximize the value of a company by proper management and effective resource allocation (Villalonga \& Amit, 2008). The concentration of control allows to marginalize the agency problems within a business entity (Claessens et al., 2002), improves performance and enhances firm value.

Our research aim is to add to the existing literature on pyramids and to explore the effects of pyramidal ownership. Using the unique sample of 162 nonfinancial companies listed on the Warsaw Stock Exchange in years 2010-2014 we investigate the effect of the pyramid, the combined effect of pyramids and the use of dual class shares, the combined effect of pyramid and ownership concentration as well as the combined effect of pyramids, ownership concentration and the use of dual class shares on company value.

Our study contributes to the existing literature on ownership structure in general, and adds to the current understanding of the effect of control leverage on company value, in particular. Firstly, while the existing studies use the measure of the adoption versus non-adoption of a pyramid or the stake controlled by the ultimate shareholder, they fail to address the simultaneous effect of the pyramid in combination with other attributes of ownership structure. This paper attempts to fill the gap in the existing literature on posttransition countries by examining the combined effect of a pyramid structure and dual class shares, the combined effect of pyramidal structure and ownership concentration as well as the combined effect of pyramids, ownership concentration and the use of dual class shares on company value.

Secondly, the study provides a perspective of the link between the adoption of a pyramid and selected ownership attributes and company value in an underdeveloped capital market. Our study extends the analysis by Holmén and Högfeldt (2009) by addressing the efficient monitoring notions in the context of control leverage and the wedge between control and cash flow rights characterized with different agency conflicts. Apart from studies on
China (Su, 2015), there is no research on pyramids in the post-transition context. To the best of our knowledge, it is the first analysis of the effects of pyramids in the largest Central European economy. Pyramids exemplify a relatively recently emerged ownership pattern with a significant potential for the coordination and financing mechanisms in the specific institutional environment of posttransition economy.

\section{Literature Review}

Pyramids are prevalent in both emerging and developed markets around the world (Claessens et al., 2000; Perkins et al., 2014; Shah et al., 2020) and are employed by family controlled firms (Attig et al., 2004; Claessens et al., 2002; Luo et al., 2021; Wang et al., 2020), by corporate owners in holdings (Bae \& Jeong, 2007; Bank \& Cheffins, 2010 Han Kim \& Kim, 2008), and by governments as state owned enterprises (SOEs) (Su et al., 2008; Su et al., 2018). Pyramids are popular in continental Europe in Sweden (Holmén \& Högfeldt, 2009), Belgium (Renneboog, 1999) and Italy, as well as in Canada (Mindzak \& Zeng, 2018; Morck, 2005). They function also in East Asia, found in $67 \%$ of companies in Indonesia, 55\% in Singapore and $49 \%$ in Taiwan (Attig et al., 2004) and in Latin America (Espinoza-Méndez et al., 2018). Pyramids combined with ownership concentration are revealed in the post-transition economies of Central and Eastern Europe (Bedo \& Acs, 2007; Hardi \& Buti, 2012; Yurtoglu, 2003) and Asia (Su, 2015).

Pyramids reveal unique structural and financial characteristics (Perkins et al., 2014; Almeida et al., 2011) and create a specific environment for investment and governance ( $\mathrm{Su}, 2015)$. They constitute a setting in which "the controlling shareholder owns one corporation through another which he does not totally own" (Faccio \& Lang, 2002, p. 366). The multiple chain of control refers to the control of a company by the ultimate owner through a number of entities which form the chain of control. The links are strengthened with interlocking directorates, simultaneously lowering the risk of concentrated ownership (Demsetz \& Lehn, 1985). In a pyramid, the group interest dominates over the goals of affiliated companies (Atavasov et al., 2011; Edward \& Weichenrieder, 2009; Marchica \& Mura, 2005; Morck et al., 2005) The con- 
trolling shareholder influences decision-making over the portfolio companies with respect to profit distribution, investment policy and related party transactions (Hussain et al., 2019, Khanna \& Palepu, 2000; Pursey et al. 2008).

Despite a growing number of studies, the emergence and existence of pyramids remain far from being understood (Almeida \& Wolfenzon, 2006), as analyses provide mixed observations leading to inconclusive results. As mentioned above, observations question the previously recognized motives and consequences of pyramidal ownership. In effect, despite the growing interest in pyramids, "no formal theory explains their presence or absence of this important and controversial business form, whether in historical or cross country terms" (Bank \& Cheffins, 2010, pp. 437-438). The competitive views indicate that the phenomenon of pyramids is significantly more complex than was initially thought.

\section{Pyramidal Ownership}

The existing literature on corporate governance provides numerous explanations on how exactly the pyramidal structure works and how it influences company value. Controlling shareholders enjoy the wedge between cash flow and control rights what may motivate them to use their power and act at the expense of minority investors (Young et al., 2008). Control leverage exacerbates the principal-principal conflicts, increases agency costs and results in the expropriation of minority investors by large shareholders, who may engage in a wide range of related party transactions (Bozec et al., 2010; Claessens et al., 2002; Shah et al., 2020). Such opportunities could be even more appealing when the divergence between control and cash flow rights is large (Baek et al., 2004). The exploitation occurs at the expense of the market valuation. However, the exact reasons behind the value discount associated with the implementation of the means of enhancing control, in general, and the pyramidal structure, in particular, are unclear, as well as the significance of the effect (Buchuk et al., 2014).

The pyramid structure also leads to the principalprincipal conflicts as well as problems of overinvestment and increased risk-taking manifested among ultimate shareholders who own excess voting rights, which is recognized as one of the primary features having a detrimental effect on performance and company value. Owing to the separation of control rights and cash flow rights, the controlling owners make investment decisions which are profitable for them but neither for other shareholders nor for the company as a whole (Morck et al., 2005; Almeida \& Wolfenzon, 2006). They aim at increasing the current cash flow instead of expanding future growth opportunities (Holmén \& Högfeldt, 2009). The control leverage allows them to reduce their own cost of mismanagement. Bany-Ariffin et al. (2010) find that pyramidal groups in Malaysia invest significantly more than non-pyramidal affiliates despite having virtually identical growth opportunities, which indicates suboptimal capital expenditure. The phenomenon of overinvestment can be explained by the principal-principal conflicts and the controlling owner's empire-building motives (Young et al., 2008). This problem does not apply to those companies with the smallest degree of separation (Bany-Ariffin et al., 2010), where the ultimate shareholders are more exposed to the negative consequences of their financial decisions.

Lemmon and Lins (2003) also investigate the effects of control leverage on firm value during the financial crisis in East Asia. They find evidence for the negative relationship between cash flow rights leverage and cumulative stock returns. However, the separation of cash flow and control only affects the value in the presence of the above-median control rights in the hands of the largest shareholder. Interestingly, there is no significant influence from the divergence between control rights and cash flow rights during the pre-crisis period. A remarkable vulnerability to economic shocks is a crucial finding regarding the link between pyramiding and corporate performance. Boubaker (2007) notes that the implementation of a pyramidal structure leads to a large devaluation among companies on the French Stock Market, regardless of the controlling owner's identity. On the basis of the regression analysis, an average pyramidaffiliated firm is worth over $50 \%$ less than an unaffiliated one.

In the competitive view, effects of pyramids are more complex than initially expected emphasizing the benefits of coordinated investment and monitoring. Strikingly, the positive effects of pyramidal 
ownership are reported in more recent studies. For instance, Lin and Yeh (2020) on a sample of Taiwanese business groups show that that pyramidal ownership improves investment efficiency suggesting that different types of control-enhancing structure do not lead to previously identified conflicts in the form of related party transaction. In addition, pyramids enjoy benefits of connectedness amongst affiliated companies, access to wide range resources as well as sharing the risk of new projects between the controller and the minority shareholder (Gama $\&$ Bandeira-de-Mello, 2020). In the study on Chinese business groups Su et al. (2018) reveal that risk-taking is conducive to enhancing firm value and is one of the important channels through which state-pyramidal layers increase firm value. Pyramids are also found to moderate agency conflicts, in particular the conflicts between shareholders and managers (Wang et al., 2020) and offer financial support for affiliated companies in the case of financial distress (Buchuk et al., 2020). In the study on South Korea Choi et al. (2021) find that controlling owners tend to increase long-term R\&D expenditures. Importantly, the R\&D investments are "more significant for firms for which the owners have low cash-flow rights, firms located in the lower layers of the pyramid, and firms that hold less equity shares than do other group affiliates" (Choi et al., 2021, p. 1). Similar evidence is noted in the study on pyramids in China (Luo et al., 2021). Finally, Ly and Duc (2018) in their study in Vietnam show that the pyramid ownership plays an important role in the effect of corporate governance on firm value.

Further, pyramidal ownership is perceived as a coordination mechanism which may be efficient in the weaker environment providing hierarchies to compensate for institutional void. Thus, pyramids may provide for more efficient allocation and investment decisions. Buchuk et al. (2014, p. 191) argue that "the link between pyramids groups and the expropriation of minority shareholders is not an unquestionable axiom," since it is not the issue of control but the efficient monitoring hypothesis that explains the rationale behind the formation of pyramids. Control leverage motivates large shareholders for active engagement and offers better control over executives. The active controlling shareholder in allocating funds efficiently under the circumstances of market imperfections, costly access to external financing and insufficient investor protection funding for new ventures and efficiently allocates it to more promising entities (Bena \& Ortiz-Molina, 2013). Thus, the wedge between cash flow and control rights can be viewed as a natural compensation to the controlling shareholder for the additional governance over the chain of affiliated companies (Claessens et al., 2002; Gilson and Schwartz, 2013), the benefits of which are also enjoyed by minority shareholders. In addition, a controlling shareholder may actively invest within internal capital market and mitigating information asymmetry transfer funds from divisions with positive cash flow to financially constrained affiliated firms (Khanna \& Palepu, 2000). Thus, a controlling shareholder can use retained earnings within the pyramid to set up new ventures more efficiently when the cost of external financing is higher than the cost of internal funds (Gonenc et al., 2007). In addition, he can "share the new firm's non-diverted payoff with minority shareholders of the original firm" (Almeida \& Wolfenzon, 2006, p. 1). This is particularly important for companies with high investment requirements and business groups (Almeida \& Wolfenzon, 2006), firms with lower profitability and higher information asymmetry (Masulis et al., 2011) or companies operating under the condition of costly access to external financing and insufficient investor protection (Gonenc et al., 2007). According to prior studies, the institutional context determines transaction costs and affects the economic outcomes of particular organizational structures (Khanna \& Rivkin, 2001). Thus, coordination offered by pyramidal structure may be an optimal solution in post-transition economies with weaker institutional environment and poorer access to external financing.

Therefore, adopting the hypothesis of the efficient monitoring by pyramids, the following hypothesis is proposed:

Hypothesis 1: Ownership by a pyramid is associated with higher company value.

\section{Pyramids and Dual Class Shares}

Dual class shares are commonly used in numerous countries (Claessens et al., 2000; Faccio \& Lang, 2002; La Porta et al., 1999). The adoption of dual class shares 
introduces a different voting scheme, departing from the 'one share - one vote' rule and increasing the control of owners (Adams \& Ferreira, 2008; Bennedsen \& Nielsen, 2010). The deviation from the 'one share - one vote' principle allows them to maintain control over an expanding company without owning a proportionate equity stake. Dual class shares are adopted less frequently than pyramids (Almeida \& Wolfenzon, 2006; Jara-Bertin et al., 2008). Their effects remain unexplored in the existing literature.

Corporate governance literature shows that the use of dual class shares by the controlling shareholder in a pyramid increases the separation between ownership and control and exacerbates principal-principal conflict and agency costs. With their use the excessive wedge between cash flow and control rights increases making the overinvestment problem more severe. As argued by Holmén and Högfeldt (2009, p. 140), "a smaller amount of private benefits associated with overinvestment is needed in order to trigger the controlling owners to overinvest". Large shareholders who choose dual class share structures are driven by "the desire of controlling shareholders to retain control without having to bear excessive cash flow risk" (Adams and Ferreira, 2008, p. 58). Excess voting rights may provide incentives and abilities to expropriate minority shareholders and generate private benefits with very limited consequences (Bozec et al., 2010). The growing separation makes the losses of the investment less costly to the controlling shareholders as these expenses are shared disproportionately by noncontrolling shareholders (Holmén \& Högfeldt, 2005).

Previous studies reveal the effects of the use of dual class shares for investment and governance, yet the results remain mixed indicating that the effects of dual class shares on firm value are far from being understood. Some studies document the value discount and suggest that control-increasing mechanisms are associated with a value discount (Claessens et al., 2002; Lins, 2003; Holmén \& Nivorozhkin, 2007; Adams \& Ferreira, 2008; Shah et al., 2020) resulting from related party transactions and expropriation of minority shareholders (Aldrighi et al., 2018). Using a sample of non-financial Korean firms, Baek et al. (2004) show that firms with high divergence between cash flow rights and control rights of controlling shareholders experienced significantly lower holding period returns during the financial crisis in 1997. The findings of Claessens et al. (2002), drawn from analysis of data from eight East Asian economies, are consistent with those obtained by Baek et al. (2004). They show that the value discount increases with the size of the wedge between control rights and cash flow rights, while none of the analyzed control-enhancing mechanisms (pyramiding, cross-holding, dual-class shares) has a significant individual effect on firm valuation.

Yet, some studies emphasize the positive impact of dual class shares on company performance (Anderson \& Reeb, 2003) indicating the additional monitoring by this mechanism. Specifically, dual class shares may limit the interference by uninformed outside shareholders, protect human capital investment by managers and assure managers' property rights (De Angelo \& De Angelo, 1985). In addition, the existing literature on takeovers and acquisitions document that dual class shares help mitigate agency problems (Taylor \& Whittred, 1998) and may serve as a monitoring mechanism to prevent an undesired takeover (Amoako-Adu \& Smith, 2001). Smart and Zutter (2003) argue that the dual-class structure provides private benefits. This would mean that adopting a pyramid structure and dual class shares simultaneously adds to the benefits of the controlling shareholder, who, discouraged from behaving opportunistically, engages in efficient allocation of funds across affiliated firms within a business group. This may be particularly important in the case of dynamically developing firms that require large investment, with the seminal examples of prominent US companies, including Google, Facebook, or Nike, that use dual class shares. The increased power of the controlling shareholder would matter more in the context of weaker institutional environment.

We follow the monitoring notion and assume that the increased control exerted by the use of dual class shares is correlated with lower agency costs and leads to the greater engagement and better monitoring by controlling shareholders. We formulate the following hypothesis 2:

Hypothesis 2: The combination of pyramid and dual class share is associated with lower company value.

\section{Pyramids, Dual Class Shares and Concentrated Ownership}

Pyramids are viewed as an alternative for ownership concentration. With each subsequent layer in the pyramid the control leverage increases, leading to stronger effects of risk diversification and lower 
capital involvement (Demsetz \& Lehn, 1985; Holmén \& Högfeldt, 2009). The resulting wedge between control rights and cash flow rights is the most direct benefit for controlling shareholders (Cronqvist \& Nilsson, 2003). It generates risk sharing opportunities (Nenova, 2003), but also offers the compensation for the additional governance (Claessens et al., 2002; Gilson \& Schwartz, 2013). This means that - following the logic of control leverage - the dominant owner should decrease his/her capital engagement in ownership up to a level which allows for control (Renneboog, 2000; Zattoni, 1999).

Concentrated ownership is one of the most important mechanisms of corporate governance with the main benefits of providing monitoring and control over executives and improving performance. While the results on the effect of concentrated ownership remain mixed, many studies indicate the positive role of majority shareholders (Maug, 1997; Shleifer \& Vishny, 1997). The significant engagement in ownership, particularly driven by the motivation to find new companies on the internal capital market, motivates large investors to efficient governance and management. Concentrated ownership reduces agency costs, assures better oversight, and is associated with higher firm value (Shleifer \& Vishny, 1997). As a consequence, the positive impact of the majority shareholder may reduce the agency problems (Holmén \& Högfeldt, 2009), and allocating funds to promising firms leads to higher company value. When a pyramid is combined with significant ownership the majority shareholder appears not to be driven by the motivation to control the excessive voting rights but rather to provide access to entire cash flows of business groups (Buchuk et al., 2014). Villalonga and Amit (2008) analyze the links between family management and company value using a sample of companies listed on the Fortune 500 list. They find that the presence of founders in the top managerial positions, as well as the high cash flow in the hands of large shareholders, are associated with a high value of Tobin's Q.

Yet, the emergence of pyramids in the context of concentrated ownership, found in companies across the globe, raises significant questions. The strongest benefits from forming such structure appear with the subsequent increase of the number of levels in a pyramid. But, the increase of ownership concentration requires greater (not lower) investment by controlling shareholder. The substantial investment of a blockholder in ownership challenges the reasoning for the adoption of the pyramid, since it neither offers the benefits of risk diversification nor leverages control. Adopting a pyramid has the opposite effect to ownership concentration and may seem pointless (Morck, 2005; Renneboog, 1999; Zattoni, 1999) unless the separation between control and cash flow rights is not the prime motivation for the controlling shareholder. We follow the efficient monitoring rationale that suggests that in the majority shareholder of a pyramid adds to firm value owing to better supervision and the reduced agency costs. We formulate the following hypothesis 3 :

Hypothesis 3: The combination of pyramid and concentrated ownership is associated with higher firm value

In addition, we also argue that the positive effect of the blockholder ownership which is reinforced with the adoption of the disproportionate ownership mechanisms including both dual class shares and pyramids. The simultaneous effect of these mechanisms increases monitoring by controlling shareholders. While the existing literature does not provide for evidence of the concurrent adoption of these three corporate governance mechanisms, we expect the positive link between the combined effect of the use of a pyramid, concentrated ownership and dual class shares versus firm value. Therefore, adopting the efficient monitoring hypothesis, the following hypothesis 4 is proposed:

Hypothesis 4: The combination of pyramid, concentrated ownership and dual class share is associated with higher company value

\section{Data Description and Methodology}

\subsection{Data}

Our sample covers data from non-financial companies listed on the Warsaw Stock Exchange during the years 2010-2014. We provide for a balanced representation of the overall population of listed companies adopting the following procedure. Firstly, we select 200 companies in terms of market capitalization as of 2010 equally distributed over the whole 
population of firms with a total of 332 non-financial listed companies at the time ${ }^{1}$. This means that we obtain the representation for the largest, medium and the smallest companies listed on the Warsaw Stock Exchange. Due to missing information related to the restrictions of databases and access to data on ownership structure (pyramidal ownership, dual class shares) we obtain the final sample of 162 nonfinancial firms.

We collect data on financial performance for sample companies, including market capitalization, from the Emerging Market Information System (EMIS) database. Information on the ownership structure, including the percentage of stakes by notified shareholders, and the type of the largest shareholder, according to the adopted classification and the use of dual class shares, was taken from the EMIS database and verified by hand with the information from annual reports and consolidated financial statements which provide more detailed material. In addition, we manually collect information on the adoption of the pyramid by studying the data disclosed in the annual report and consolidated financial statement. We consider information on the characteristics of pyramidal structures, such as the number of levels and the identity of the controlling entities and ultimate shareholders using the $\mathrm{Na}$ tional Court Register (KRS). The access to the information on company chains is significantly limited since the lack of disclosure requirement for parent or intermediary companies set up within pyramids. To categorize the structure as a pyramid we use the classical definition, which identifies pyramidal ownership as being when the listed company is controlled by a chain of entities forming multiple layers (Bennedsen and Nielson, 2006; Perkins et al., 2014). The value of the company, as measured by Tobin's Q serves as the explained variable. The ownership characteristics, including the adoption of the pyramid, ownership concentration and the use of dual class shares are used as explanatory variables. Assets and debt are our control variables. The data on ownership structure and financial performance refer to listed companies.

In the process of sample collection, we exclude nearly 35 companies due to missing data on ownership structure. Additional 3 companies are removed from the analysis as they reveal outlying values of the explained variable of $\mathrm{Q}$. We end with the final sample of 162 companies.

\subsection{Methodology}

We operationalize the variables used in the analysis following the approach adopted in prior studies on ownership structure, in general (Djebali \& Belanes, 2015), or pyramids, in particular (Bozec et al., 2010). Specifically, we follow the approach adopted by Bozec et al. (2010) in the study on Canada and employ a binary variable depicting the use of pyramids. We use the percentage of stake by the largest shareholder to measure the effect of ownership concentration (Bedo \& Acs, 2007). Similarly, the percentage of company shares held by distinct categories of shareholders was utilized to measure the effect of ownership by state, industry investor, CEO and financial investor respectively (Florackis et al., 2015). In the analysis we control for value of company assets and debt, which are standard control variables (Sánchez-Ballesta \& García-Meca, 2007). We use Tobin's Q to represent a firm's market value (Baek et al., 2004; Boubaker, 2007; Claessens et al., 2002; Villalonga \& Amit, 2008).

For econometric modeling of changes in Tobin's $Q$ value among companies adopting pyramidal ownership structure we use observational, cross-section and panel data for the period 20102014. This means that the sample of analyzed companies is the same and the sample selection is not random but purposive. Thus, the obtained results may be biased with the selection sample error, which turns out to be a frequent problem for research on microdata. The lack of random sample selection stems from our intention to collect a coherent and complete data set containing a significant number of non-financial companies. Under these assumptions we construct a balanced panel data sample of 810 observations, that is, for 162 firms over 5 years.

The analyzed variables include quantitative as well as qualitative data. The former represents continuous measurement scale data, while the latter is the category of non-continuous measurement scale data. This differentiation provides 
a challenge to the estimation and interpretation of model parameters. Thus, the ceteris paribus rule, which is widely recognized and adopted in economic research, cannot be properly used in this case (Wooldridge, 2000).

The number of variables initially considered for the analysis was significantly larger than the number of variables used in the econometric modeling. The econometric model is built with the use of variables selected on the basis of the variance-inflating factor (VIF) and the statistical significance tests run during the modeling process. Table $1 \mathrm{de}$ scribes the variables used in the analysis.

In the sample companies Tobin's $\mathrm{Q}$ and ROA variables reveal variability both over the analyzed period of time and for the sector of operation. Prior research (Vintila and al., 2014; Cornett et al., 2007) use the adjustment procedure of the measures correcting the original values by median value. The use of median instead of average is driven by the strong asymmetry of variables distribution. Two approaches of the adjustment are adopted - in the first one the variable is corrected by subtracting median value from the original value of a given variable for the sector and year. For instance for Tobin's Q the procedures is as follows:

$\operatorname{Qadj}_{i t}=Q_{i t}-$ median $Q_{S E, t}, i=1, ., 162 ; t=1, ., 5 ;$

whereas in the second operation additionally lowers the dispersion of the corrected values accordingly:

$\operatorname{Qadj}_{i t .}=\operatorname{sign}\left(Q_{i t}-\operatorname{median} Q_{S E . t .}\right)$

$\cdot \sqrt{\mid Q_{i t}-\text { median } Q_{S E, t} \mid}, i=1, ., 162 ; t=1, ., 5$,

where SE indicates the sector of operation and $\operatorname{sign}()$ stands for the sign of the difference. We adopt the first approach for the adjustment of $\mathrm{Q}$ and ROA values, since the correction with the use of the second approach leads to the emergence of endogeneity of variables in the constructed econometric models.

To explain the link between firm value and ownership structure, variables such as the adoption of a pyramid, the combination of a pyramid and the use of dual class shares, the combination of a pyramid and ownership concentration by the largest shareholder, and the combination of a pyramid, the use of dual class shares and ownership concentration by the largest shareholder, we construct sequence of linear econometric models for panel data (Koop, 2008).

Our sample remains stable over the analyzed period with respect to the type of the largest shareholder. The individual investor is the largest shareholder in $35 \%$ of the sample companies, followed by domestic industry investor (27\%) and foreign industry investor (17\%). In the case of $14 \%$ of the sample companies, the financial investor is the largest shareholder, while in $7 \%$ of companies it is the state. A similar stability is noted in the case of pyramidal ownership, with $54 \%$ of the sample companies using pyramids. In addition, $21 \%$ of the sample companies adopt dual class shares.

We report the distribution of Tobin's Q in Table 2. For each analyzed year the distribution of $\mathrm{Q}$ reveals a positive asymmetry, with a greater number of observations with low values of $\mathrm{Q}$ than with high values of Q. We consider companies with Tobin's Q value higher than 3 as the outliers and exclude them from the research sample.

The right asymmetry of Tobin's Q distribution imposes significant consequences on the analysis as it determines the type of descriptive statistics for this variable. Specifically, the distribution asymmetry of the explained variable makes the classic measures of descriptive statistics, such as arithmetic mean less informative. Rather, the use of positional statistics measure such as median is more adequate. Table 3 presents the arithmetic mean and the median of Tobin's $Q$ variable for sample companies in the analyzed period with the breakdown for years and sectors of operations. As shown 84 sample companies operate in industry, 20 companies in construction, 7 companies in the energy sector, while the service sector is represented by 51 firms.

As reported in Table 3, the variability of mean and median values for Tobin's $Q$ requires the adjustment of the variables with respect to the length of the analyzed period as well as sectors in which sample firms operate. Over the sample, the mean value is largest than the respected median value for both the whole analyzed period and for each year separately 
Table 1

Variables Used in the Econometric Analysis

\begin{tabular}{|c|c|c|}
\hline Variable name & Variable description & Variable type \\
\hline$Q$ & Tobin's Q ratio & Quantitative, real \\
\hline Qadj & Sector-adjusted Tobin's Q ratio & Quantitative, real \\
\hline PYRAMID & Adoption of pyramid [ 1 - yes, 0 - no] & Qualitative, binary \\
\hline \multirow[t]{3}{*}{ BUSGROUP } & Information whether the firm functions as & Qualitative, binary \\
\hline & the affiliated company within a business group & \\
\hline & {$[1-$ yes, $0-$ no $]$} & \\
\hline DUALCLASS & Adoption of dual class [ $1-$ yes, $0-$ no] & Qualitative, binary \\
\hline LARGSHARE & Stake of the largest shareholder [\%] & Quantitative, real \\
\hline DUAL_LASH & Combination of the dual class shares by the first largest shareholder & Quantitative, real \\
\hline PYR_DUAL & Combination of the adoption of pyramidal structure and dual class shares & Qualitative, binary \\
\hline PYR_LASH & Adoption of the pyramidal structure by the first largest shareholder & Quantitative, real \\
\hline PYR_DUAL_LASH & Combination of the adoption of pyramidal structure and dual class shares & Quantitative, real \\
\hline & by the first largest shareholder & \\
\hline ln_ASSETS & Natural logarithm of assets [million PLN] & Quantitative, real \\
\hline ln_EMPT & Natural logarithm of employment $[\mathrm{FTE}]$ & Quantitative, real \\
\hline ln_LTLIAB & Natural logarithm of long term liabilities [million PLN] & Quantitative, real \\
\hline \multirow[t]{2}{*}{ ln_STLIAB } & Natural logarithm of short term liabilities & Quantitative, real \\
\hline & [million PLN $]$ & \\
\hline ROAadj & Sector-adjusted return on assets [\%] & Quantitative, real \\
\hline ROE & Return of equity $[\%]$ & \\
\hline LTLIAB/ASSETS & $\begin{array}{l}\text { The size of long term liabilities divided by the company size in value of } \\
\text { assets [\%] }\end{array}$ & Quantitative, real \\
\hline LTLIAB/TOTEQ & $\begin{array}{l}\text { The size of long term liabilities divided by the company size in value of } \\
\text { equity [\%] }\end{array}$ & Quantitative, real \\
\hline
\end{tabular}

which indicate asymmetric distribution of Tobin's $Q$ ratio. The distribution of explained variable and explanatory variables values have a significant impact for the estimated models, based on the balanced panel. The distribution of values is shown in Table 4.

The distribution of variables values imposes limitations to obtain sound statistical effect in econometric modeling. As reported in Table 4 only distributions of $1 n \_$EMP, ln_LTLIAB and ln_STLIAB values are similar to symmetric, while for Qadj, LARGSHARE and ROAadj variables we note asymmetric distribution. The distributions of ROE and quotients LTLIAB/ASSETS and LTLIAB/ TOTEQ remain extremely asymmetric as well.
Table 5 presents descriptive statistics of used variables, which are not qualitative measures. The characteristics of binary variables is discussed below.

The analysis of the values of statistical measures for pairs of variables (Q, Qadj) and (ROA, ROAadj) indicates that the adopted adjustment of Q and ROA variables value with respect to sector of operation influences the scope of variability of Qadj and ROAadj variables. The adjustment procedure lowers the median value of these variables to 0 what is a consequence of the subtraction of the sectorial median from $\mathrm{Q}$ and ROA values. The adjustment procedure has no impact on the value distribution with respect to variability, skewness, and kurtosis. The analysis reveals that the values of ROA and ROE 
Table 2

Distribution of Tobin's Q, 2010-2014

\begin{tabular}{|c|c|c|c|c|c|}
\hline Value & 2010 & 2011 & 2012 & 2013 & 2014 \\
\hline $0-0.25$ & 9 & 49 & 40 & 32 & 42 \\
\hline $0.25-0.50$ & 48 & 59 & 61 & 44 & 50 \\
\hline $0.50-0.75$ & 29 & 19 & 22 & 39 & 30 \\
\hline $0.75-1.50$ & 58 & 31 & 32 & 33 & 29 \\
\hline $1.50-2.70$ & 18 & 4 & 7 & 14 & 11 \\
\hline
\end{tabular}

Table 3

Mean and Median Values for Tobin's Q, 2010-2014

\begin{tabular}{lccccccc}
\hline Data & Measure & $\mathbf{2 0 1 0 - 2 0 1 4}$ & $\mathbf{2 0 1 0}$ & $\mathbf{2 0 1 1}$ & $\mathbf{2 0 1 2}$ & $\mathbf{2 0 1 3}$ & $\mathbf{2 0 1 4}$ \\
All sample & Mean & 0.610 & 0.806 & 0.494 & 0.533 & 0.657 & 0.562 \\
& Median & 0.463 & 0.670 & 0.393 & 0.397 & 0.521 & 0.412 \\
Industry & Mean & 0.640 & 0.810 & 0.497 & 0.570 & 0.721 & 0.606 \\
& Median & 0.496 & 0.710 & 0.408 & 0.421 & 0.567 & 0.480 \\
Construction & Mean & 0.341 & 0.534 & 0.311 & 0.286 & 0.307 & 0.264 \\
& Median & 0.287 & 0.562 & 0.249 & 0.301 & 0.260 & 0.158 \\
Energetics & Mean & 0.592 & 1.031 & 0.494 & 0.541 & 0.468 & 0.427 \\
& Median & 0.497 & 0.805 & 0.522 & 0.473 & 0.368 & 0.371 \\
Services & Mean & 0.668 & 0.873 & 0.561 & 0.568 & 0.714 & 0.619 \\
& Median & 0.511 & 0.754 & 0.436 & 0.408 & 0.564 & 0.433 \\
\hline
\end{tabular}

are instable for sample companies with the scope of variability beyond values which are rationally interpretable in business research. Despite the identification of this variability, we do not adjust the value assuming they do not impact the quality of constructed econometric models. The run test supports the hypothesis of the normal distribution for ln_STLIAB variable. The distribution of other variables does not positively perform this test what results from the variability of these variables (Table 4) and the measures of their skewness and kurtosis (Table 5).

We employ a Pearson correlation coefficient to measure the strength and direction of interdependence of the used variables, assuming linear relations between them. The correlation for pairs of variables (Q, Qadj) and (ROA, ROAadj) remain very high, close to 1 . We also accept the limitations of the correlation measure used for binary variables. In Table 6 we report the Pearson correlation coefficients for variables used in the analysis.

As shown in Table 6, the variables of the company size, firm performance and indebtedness are higher correlated with the firm value measured by Tobin's $Q$ than the variable on the adoption of a pyramidal structure, operation within a business group and ownership concentration measured by the stake by the largest shareholder.

Table 6 reports statistically significant correlation between Qadj and BUSGROUP and statistically insignificant correlation between Qadj and PYRAMID. The largest values of correlation are noted between explanatory variables constructed as quotients of the used variables. While the correlation remains a natural result of the construction procedure of these measures, it requires to run multicollinearity test for explanatory variables used in the econometric modeling. 


\section{Table 4}

Histograms of Explained and Explanatory Variables

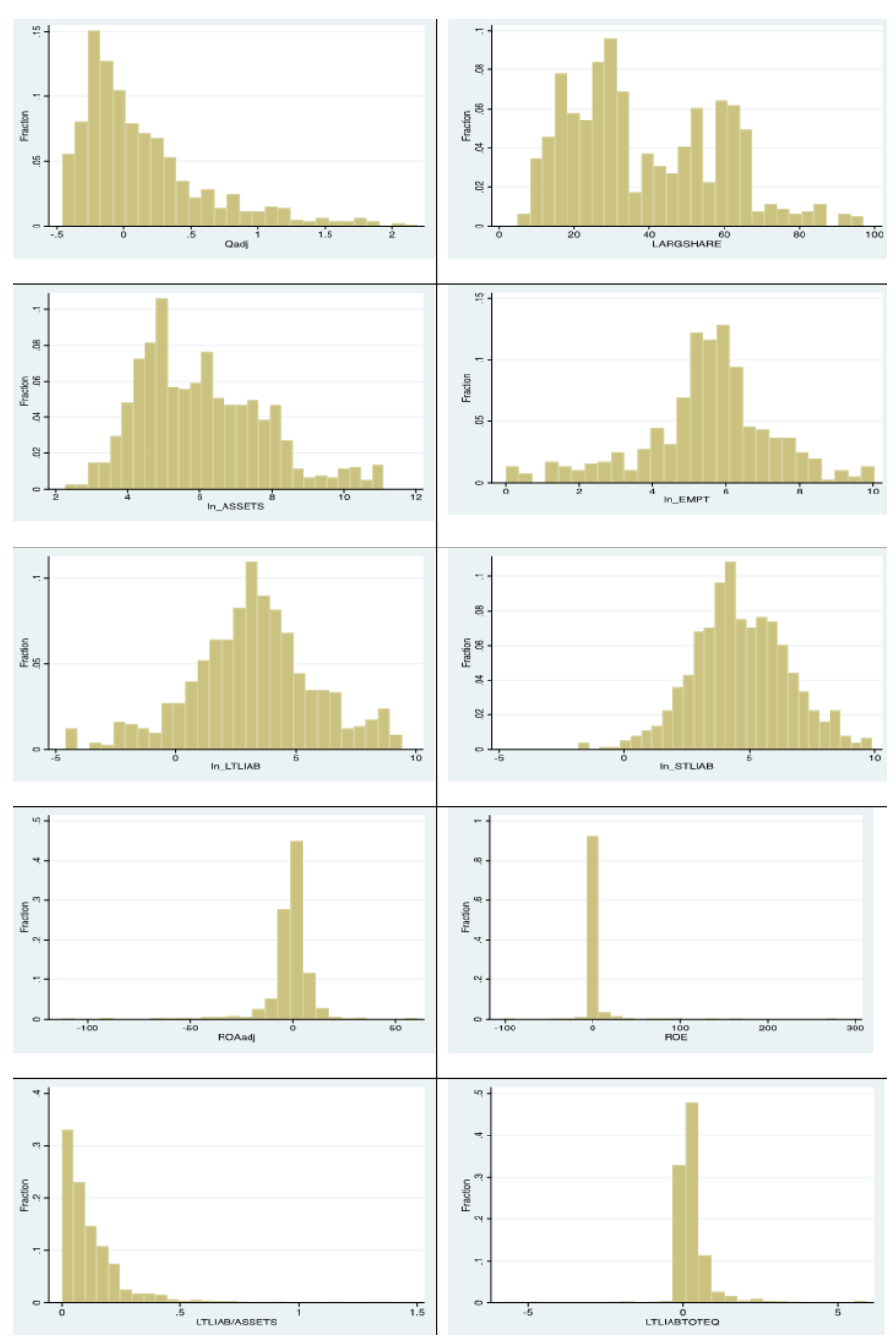

\section{Empirical Results}

\subsection{Regression Results}

We employ the following strategy for our econometric modeling. The analysis of the variability of Qadj we note that the variability over time (standard deviation within for Qadj equals 0.272) and between sample companies (standard deviation between for Qadj equals 0.398$)$ ) is statistically significant. Thus, we test parameters with the use of two-way effects model (Cameron and Trivedi, 2005). We introduce the artificial variables to model the changes (variability) of Qadj variable over time for all constructed econometric models. Then, we consider the use of random effects model and fixed effects model for each set of analyzed variables. The Hausman test indicates 
that fixed effects are more appropriate approach for our study. The analysis of multicollinearity for the set of explanatory variables for each model is negative. In addition, we test homoscedasticity of the random parameter noting that the use of estimators robust for heteroscedasticity is not needed. We also test for the endogeneity of the explanatory variables in the constructed models. The introduction of the explanatory variable of $\ln \_$ASSETS into the model leads to the increase of the correlation between random parameter with this variable. Therefore, we eliminate ln_ASSETS from our models. Calculations are run in STATA15 software. The tabulations of the estimated models are presented in Table 7.

All econometric models reported in Table 7 are linear models with respect to the parameters used. Model F is constructed using the following specification:

$$
\begin{aligned}
& \text { Qadj }_{i t}=\alpha+\beta_{1} \text { PYRAMID }_{i t}+\beta_{2} \text { BUSGROUP }_{i t} \\
& +\beta_{3} \text { DUALCLASS }_{i t}+\beta_{4} \text { LARGSHARE }_{i t}++\beta_{5} \text { DUAL_LASH }_{i t} \\
& +\beta_{6} P Y R_{-} D U A L_{i t}+\beta_{7} P Y R_{-} L A S H_{i t}+\beta_{8} P Y R_{-} D U A L_{-} L A S H_{i t} \\
& +\beta_{9} \ln _{-} E M P T_{i t}+\beta_{10} \ln L T L I A B_{i t}+\beta_{11} \ln \_S T L I A B_{i t} \\
& +\beta_{12} \text { ROAadj }_{i t}+\varepsilon_{i t}
\end{aligned}
$$

where $\mathrm{i}=1,2, \ldots, 162$ and $\mathrm{t}=1,2, \ldots, 5 ; \beta_{1}, \ldots$ $, \beta_{12}, \alpha$ - regression coefficients; $\varepsilon_{i t}-$ composite error component, where $\varepsilon_{i t}=\mu_{i}+\lambda_{t}+\epsilon_{i t}, \mu_{i}-$ the unobservable individual-specific effect, $\lambda_{t}-$ the unobservable time-specific effect, $\epsilon_{i t}$ - the remainder disturbance.

The other econometric models are the specific case of the original initial model with the additional restrictions imposed on the parameters. For instance, model A is built according to the following assumptions:

$\beta_{2}=\beta_{3}=\beta_{4}=\beta_{5}=\beta_{7}=\beta_{8}=0$

As reported, we obtain the acceptable quality of the model estimation - we explain $20 \%$ of the change of Qadj over time [R-sq within] and 3-5\% of the change of Qadj between sample companies [R-sq between]. In general, the explanatory power of Qadj variable does not exceed $9 \%$ in models A-F.

The regression results reported in Table 7 present six different models examining the link between the use of pyramids and company value. We intend to examine the relation between pyramidal ownership and Tobin's Q, taking into account the impact of the use of dual class shares and concentrated ownership. Thus, we discuss all results reported in Table 7 but we mostly focus on the explanations provided by Model $\mathrm{E}$ and $\mathrm{F}$, which directly address our hypotheses. In our models we measure the deviation of $\mathrm{Q}$ of a given company in a given year and sector, what means that the positive sign indicates the increase of the

Table 5

Descriptive Statistics for Explained and Explanatory Variables

\begin{tabular}{lccccccc} 
Var & Min & Max & Mean & Median & St.Dev. & Skewness & Kurtosis \\
\hline Q & 0.007 & 2.684 & 0.610 & 0.463 & 0.481 & 1.515 & 5.297 \\
Qadj & -0.461 & 2.187 & 0.135 & 0 & 0.472 & 1.512 & 5.341 \\
LARGSHARE & 5.000 & 97.000 & 38.936 & 33.000 & 19.892 & 0.477 & 2.366 \\
ln_ASSETS & 2.257 & 11.100 & 6.038 & 5.812 & 1.741 & 0.651 & 3.058 \\
ln_EMPT & 0 & 10.045 & 5.472 & 5.640 & 1.816 & -0.541 & 3.936 \\
ln_LTLIAB & -4.605 & 9.402 & 3.177 & 3.196 & 2.597 & -0.223 & 3.438 \\
ln_STLIAB & -1.833 & 9.894 & 4.664 & 4.514 & 1.899 & 0 & 3.121 \\
ROA & -111.9 & 63.678 & 2.262 & 3.268 & 11.534 & -3.295 & 30.529 \\
ROAadj & -112.3 & 60.599 & -1.009 & 0 & 11.422 & -3.234 & 29.860 \\
ROE & -102.7 & 279.8 & 2.809 & 0.943 & 15.281 & 10.347 & 165.2 \\
LTLIAB/ASSETS & 0 & 1.384 & 0.122 & 0.083 & 0.143 & 3.408 & 22.445 \\
LTLIAB/TOTEQ & -5.750 & 5.919 & 0.295 & 0.151 & 0.637 & 1.717 & 39.569 \\
\hline
\end{tabular}


Table 6

Pearson Correlation Coefficients between Variables

\begin{tabular}{|c|c|c|c|c|c|c|c|c|}
\hline Var & (1) & (2) & (3) & (4) & (5) & (6) & (7) & (8) \\
\hline Qadj (1) & 1.000 & & & & & & & \\
\hline PYRAMID (2) & 0.017 & 1.000 & & & & & & \\
\hline BUSGROUP (3) & $-0.079^{\star}$ & 0.042 & 1.000 & & & & & \\
\hline DUALCLASS (4) & $-0.079^{*}$ & $-0.089^{*}$ & $-0.070^{*}$ & 1.000 & & & & \\
\hline LARGSHARE (5) & 0.058 & $0.218^{*}$ & $-0.089^{*}$ & $-0.096^{*}$ & 1.000 & & & \\
\hline DUAL_LASH (6) & -0.012 & -0.056 & $-0.118^{*}$ & $0.867^{*}$ & $0.123^{*}$ & 1.000 & & \\
\hline PYR_DUAL (7) & 0.010 & $0.297^{*}$ & -0.025 & $0.629^{*}$ & -0.030 & $0.582^{*}$ & 1.000 & \\
\hline PYR_LASH (8) & 0.050 & $0.836^{*}$ & -0.018 & $-0.128^{\star}$ & $0.570^{*}$ & -0.026 & $0.175^{*}$ & 1.000 \\
\hline PYR_D-L_L-H (9) & 0.025 & $0.266^{*}$ & -0.010 & $0.563^{*}$ & $0.094^{*}$ & $0.667^{*}$ & $0.895^{*}$ & $0.251^{*}$ \\
\hline ln_ASSETS (10) & -0.051 & $-0.076^{\star}$ & $0.342^{*}$ & $-0.256^{*}$ & $0.131^{\star}$ & $-0.262^{\star}$ & $-0.156^{*}$ & -0.008 \\
\hline ln_EMPT (11) & $0.120^{*}$ & $-0.154^{*}$ & $0.172^{*}$ & -0.013 & -0.003 & -0.025 & 0.015 & $-0.107^{*}$ \\
\hline ln_LTLIAB (12) & $-0.108^{*}$ & 0.016 & $0.339^{*}$ & $-0.158^{\star}$ & $0.096^{*}$ & $-0.179^{*}$ & $-0.085^{\star}$ & 0.031 \\
\hline ln_STLIAB (13) & $-0.120^{*}$ & $-0.092^{*}$ & $0.404^{*}$ & $-0.171^{*}$ & 0.055 & $-0.219^{*}$ & $-0.112^{*}$ & -0.048 \\
\hline ROAadj (14) & $0.309^{*}$ & -0.019 & -0.007 & $-0.078^{*}$ & $0.079^{*}$ & -0.044 & 0.003 & 0.018 \\
\hline ROE (15) & $-0.064^{*}$ & -0.049 & $-0.111^{*}$ & 0.001 & 0.012 & 0.041 & -0.021 & -0.025 \\
\hline LT-B/ASSETS (16) & $-0.099^{*}$ & $0.131^{*}$ & $0.116^{*}$ & -0.054 & 0.003 & $-0.065^{*}$ & -0.018 & $0.081^{*}$ \\
\hline \multirow[t]{2}{*}{ LT-B/TOTEQ (17) } & $-0.059^{*}$ & $0.092^{*}$ & $0.067^{\star}$ & -0.041 & $0.110^{*}$ & -0.046 & -0.041 & $0.134^{*}$ \\
\hline & (9) & (10) & (11) & (12) & (13) & (14) & (15) & (16) \\
\hline PYR_D-L_L-H (9) & 1.000 & & & & & & & \\
\hline ln_ASSETS (10) & $-0.155^{*}$ & 1.000 & & & & & & \\
\hline ln_EMPT (11) & 0.014 & $0.512^{*}$ & 1.000 & & & & & \\
\hline ln_LTLIAB (12) & $-0.097^{\star}$ & $0.788^{*}$ & $0.405^{\star}$ & 1.000 & & & & \\
\hline ln_STLIAB (13) & $-0.138^{*}$ & $0.902^{*}$ & $0.541^{*}$ & $0.731^{*}$ & 1.000 & & & \\
\hline ROAadj (14) & 0.005 & $0.070^{*}$ & $0.196^{*}$ & 0.041 & -0.017 & 1.000 & & \\
\hline ROE (15) & 0.005 & -0.003 & -0.049 & $-0.062^{*}$ & $-0.110^{*}$ & -0.013 & 1.000 & \\
\hline LT-B/ASSETS (16) & -0.044 & $0.136^{*}$ & -0.009 & $0.506^{*}$ & $0.116^{*}$ & -0.055 & -0.019 & 1.000 \\
\hline LT-B/TOTEQ (17) & -0.054 & $0.191^{*}$ & 0.024 & $0.347^{\star}$ & $0.180^{*}$ & $-0.149^{*}$ & 0.004 & $0.358^{\star}$ \\
\hline
\end{tabular}

${ }^{*}$ stands for significance at $10 \%$.

deviation, whereas the negative sign depicts the decrease of the deviation. We assume and measure the association between analyzed variables, since as noted by Brüderl (2015) modeling the cause effect requires introducing either a step event dummy or a full set of event time dummies. Financial performance measured by ROA is important for the economic survivorship of the company - the increase of ROA deviation from the sectorial mean translates into the increase of $\mathrm{Q}$ deviation from the sectorial mean. The ROAadj parameter remains positive and significantly different from zero in all models.

The results reveal that the use of a pyramid
(PYRAMID) is associated with a higher value of Tobin's Q (Models A-F). This evidence provides support for hypothesis H1, suggesting, according to the efficient monitoring notion, the benefits of control leverage by a pyramid. Our evidence remains consistent with studies on emerging markets. Our finding does not identify an expropriation problem and supports the view that pyramid provide efficient oversight and reduce agency costs (Masulis et al., 2011; Buchuk, et al., 2014).

The use of a combination of ownership variables offers additional interpretations. Specifically, we examine the link between the combined use of a 
pyramidal structure and the adoption of dual class shares and company value. The results revealed in Models $\mathrm{E}$ and $\mathrm{F}$ show that the use of dual class shares in pyramids is negatively associated with company value. This evidence does not support our hypothesis $\mathrm{H} 2$ and remains inconsistent with analyses indicating the positive effect of dual class shares on company value (Anderson \& Reeb, 2003). At the same time however, this finding remains in line with studies that indicate the detrimental impact of dual class shares on Q (Claessens et al., 2002; Lins, 2003; Holmén \& Nivorozhkin, 2007; Adams \& Ferreira, 2008). We attribute this evidence to the possible costs related to private benefits by controlling shareholder.

In the case of ownership concentration by largest shareholders, we obtain statistically insignificant results (Models D-F). This finding provides no support for hypothesis $\mathrm{H} 3$ and suggests no effect of the use of a pyramidal structure by a blockholder for company value.

Finally, we examine the link between the combined use of a pyramid, ownership concentration and dual class shares (Koop, 2008). As reported, Models E and $F$ reveal the positive relation on Tobin's Q. If the parameters of DUALCLASS and LARGSHARE variables were stably significantly different from zero, we could use the quotient to interpret the parameters of the regressors as variables in the sample, independent from the factors measured by the quotient. However, since the parameters are not significantly different from zero, we interpret the findings as the result of conjunction. Since the parameter of PYR_DUAL_LASH variable is positive and significantly different from zero, we interpret our findings as follows: with the combined adoption of dual class shares and pyramids the increase of ownership concentration is positively correlated with $\mathrm{Q}$ higher than the sectorial mean. We interpret this finding arguing that ownership concentration offsets the negative effect of the use of dual class shares on company value. The investment by majority shareholder in the ownership structure discourages him from exploiting private benefits and motivates him to enhance firm value.

In sum, our findings suggest that control by a single investor in the form of a pyramid may serve as a mechanism for efficient monitoring (Almeida et al., 2011) and does not disproportionately distribute the costs non-controlling shareholders (Holmén \& Högfeldt, 2009; Lin \& Yeh, 2020). While the increase of the separation between control and cash flow rights are negatively associated with $\mathrm{Q}$, the combined use of a pyramid, ownership concentration and dual class shares outweighs the detrimental effect of the wedge and enhances company value.

\subsection{Robustness Checks}

To examine the robustness of our results we run several additional tests. Owing to the limitations to replace company value of $\mathrm{Q}$ with accounting measures we introduce a different set of explanatory variables (King \& Santor, 2008) to check whether our results remain stable. Firstly, we employ a different explanatory variables, replacing the measure of return on assets (ROA) with return on equity (ROE), and debt (LTLIAB) with debt versus equity (LTLIAB/TEQ). Tobin's $Q$ remains our explained variable. We test the same relationship for the use of a pyramid, the combined use of a pyramid and ownership concentration and the combined use of a pyramid and dual class shares. To assure consistency with the methodology, we construct three models for our sample companies (R1, R2 and R3). The results are presented in Table 8.

The statistical interpretation for Models R1-R3 remains identical as for Models A-F. Models R1-R3 are constructed with the use of different set of explanatory variables referring to company size and financial characteristics. Specifically, we replace ROAadj variable with LTLIAB/TOTEQ measure (in R1 model) and with LTLIAB/ASSETS measure (in R2 model). As reported in Table 8, our findings are robust with respect to the use of the alternative measures. The signs of all relevant parameters in models remain the same. Only the parameter of LTLIAB/ ASSETS variable in R1 model is not significantly different from zero. Introducing the ln_ASSETS variable denoting the company size to the model leads to a significant increase of constant value. In R3 model for explained variable of Qadj we observe the endogeneity problem. We note a similar endogeneity effect with the introducing of ROEadj variable to the models. 


\section{Table 7}

Estimation Results for Dependent Variable Q

\begin{tabular}{|c|c|c|c|c|c|c|}
\hline Qadj and & Model A & Model B & Model C & Model D & Model E & Model F \\
\hline \multirow[t]{2}{*}{ const } & 0.598 & 0.612 & 0.611 & 0.543 & 0.523 & 0.558 \\
\hline & $(0.137)^{\star * *}$ & $(0.152)^{\star * *}$ & $(0.140)^{\star * *}$ & $(0.157)^{\star * \star}$ & $(0.156)^{* \star *}$ & $(0.169)^{* * *}$ \\
\hline \multirow[t]{2}{*}{ PYRAMID } & 0.109 & 0.109 & 0.107 & 0.094 & 0.156 & 0.156 \\
\hline & $(0.051)^{\star *}$ & $(0.051)^{\star *}$ & $(0.055)^{*}$ & $(0.049)^{*}$ & $(0.094)^{*}$ & $(0.094)^{*}$ \\
\hline \multirow[t]{2}{*}{ BUSGROUP } & & -0.014 & & & & -0.035 \\
\hline & & $(0.066)$ & & & & $(0.066)$ \\
\hline \multirow[t]{2}{*}{ DUALCLASS } & & & -0.052 & -0.265 & 0.324 & 0.317 \\
\hline & & & $(0.116)$ & $(0.155)^{*}$ & $(0.247)$ & $(0.247)$ \\
\hline \multirow[t]{2}{*}{ LARGSHARE } & & & & 0.002 & 0.003 & 0.002 \\
\hline & & & & $(0.002)$ & $(0.002)$ & $(0.002)$ \\
\hline \multirow[t]{2}{*}{ DUAL_LASH } & & & & 0.007 & -0.015 & -0.015 \\
\hline & & & & $(0.004)^{*}$ & $(0.008)^{*}$ & $(0.008)^{*}$ \\
\hline \multirow[t]{2}{*}{ PYR_DUAL } & & & 0.009 & 0.025 & -0.704 & -0.707 \\
\hline & & & $(0.130)$ & $(0.133)$ & $(0.273)^{\star * *}$ & $(0.273)^{* * *}$ \\
\hline \multirow[t]{2}{*}{ PYR_LASH } & & & & -0.001 & -0.002 & -0.002 \\
\hline & & & & $(0.002)$ & $(0.002)$ & $(0.002)$ \\
\hline \multirow[t]{2}{*}{ PYR_DUAL_LASH } & & & & & 0.027 & 0.027 \\
\hline & & & & & $(0.009)^{\star * *}$ & $(0.009)^{* * *}$ \\
\hline \multirow[t]{2}{*}{ ln_EMPT } & 0.032 & 0.032 & 0.032 & 0.029 & 0.029 & 0.028 \\
\hline & $(0.020)$ & $(0.021)$ & $(0.020)$ & $(0.020)$ & $(0.020)$ & $(0.020)$ \\
\hline \multirow[t]{2}{*}{ ln_LTLIAB } & -0.034 & -0.034 & -0.035 & -0.035 & -0.034 & -0.034 \\
\hline & $(0.009)^{* * *}$ & $(0.009)^{* * *}$ & $(0.009)^{* * *}$ & $(0.009)^{\star * *}$ & $(0.009)^{\star * *}$ & $(0.009)^{* * *}$ \\
\hline \multirow[t]{2}{*}{ ln_STLIAB } & -0.082 & -0.082 & -0.082 & -0.079 & -0.078 & -0.078 \\
\hline & $(0.023)^{* * *}$ & $(0.023)^{\star * *}$ & $(0.023)^{* * *}$ & $(0.023)^{\star * *}$ & $(0.023)^{\star * *}$ & $(0.023)^{* * *}$ \\
\hline \multirow[t]{2}{*}{ ROAadj } & 0.002 & 0.002 & 0.002 & 0.002 & 0.002 & 0.002 \\
\hline & $(0.001)^{*}$ & $(0.001)^{\star}$ & $(0.001)^{*}$ & $(0.001)^{*}$ & $(0.001)^{*}$ & $(0.001)^{*}$ \\
\hline R-sq within & 0.211 & 0.212 & 0.212 & 0.220 & 0.232 & 0.232 \\
\hline R-sq between & 0.044 & 0.044 & 0.050 & 0.053 & 0.029 & 0.029 \\
\hline R-sq overall & 0.081 & 0.081 & 0.081 & 0.089 & 0.067 & 0.067 \\
\hline
\end{tabular}

Note: Standard errors of parameters are reported in parentheses. ${ }^{\star}$ stands for significance at $10 \%,{ }^{* \star}$ stands for significance at $5 \%,{ }^{* * *}$ stands for significance at $1 \%$.

In Table 7 for each model the estimation of Qadj parameters over time are omitted. For each model variables Y2011, Y2012, Y2013, Y2014 are included. They measure the mean change of Qadj value year to 2010 year which is used as the reference point. Parameters of used variables are: $-0.30,-0.29,-0.17$ and -0.26 respectively and are statistically significant. Thus, Qadj values in 2010 are the largest values on the analyzed period and lower in years 2011 and 2012 followed by a slight increase. Estimations of parameters confirm the tendencies over time documented in Table 3. 


\section{Table 8}

Estimation Results for Dependent Variable Q - Robustness Test

\begin{tabular}{|c|c|c|c|}
\hline Qadj and & Model R1 & Model R2 & Model R3 \\
\hline \multirow[t]{2}{*}{ const } & 0.503 & 0.570 & 1.160 \\
\hline & $(0.156)^{* * *}$ & $(0.156)^{\star * *}$ & $(0.236)^{\star * *}$ \\
\hline \multirow[t]{2}{*}{ PYRAMID } & 0.166 & 0.183 & 0.177 \\
\hline & $(0.094)^{*}$ & $(0.094)^{\star *}$ & $(0.093)^{*}$ \\
\hline \multirow[t]{2}{*}{ DUALCLASS } & 0.338 & 0.312 & 0.364 \\
\hline & $(0.247)$ & $(0.246)$ & $(0.244)$ \\
\hline \multirow[t]{2}{*}{ LARGSHARE } & 0.003 & 0.002 & 0.002 \\
\hline & $(0.002)$ & $(0.002)$ & $(0.002)$ \\
\hline \multirow[t]{2}{*}{ DUAL_LASH } & -0.015 & -0.014 & -0.016 \\
\hline & $(0.008)^{*}$ & $(0.008)^{*}$ & $(0.008)^{* *}$ \\
\hline \multirow[t]{2}{*}{ PYR_DUAL } & -0.700 & -0.680 & -0.813 \\
\hline & $(0.273)^{\star *}$ & $(0.272)^{\star \star}$ & $(0.272)^{\star * *}$ \\
\hline \multirow[t]{2}{*}{ PYR_LASH } & -0.002 & -0.002 & -0.002 \\
\hline & $(0.002)$ & $(0.002)$ & $(0.002)$ \\
\hline \multirow[t]{2}{*}{ PYR_DUAL_LASH } & 0.027 & 0.026 & 0.029 \\
\hline & $(0.009)^{* * *}$ & $(0.009)^{* * *}$ & $(0.009)^{* * *}$ \\
\hline \multirow[t]{2}{*}{ ln_EMPT } & 0.033 & 0.035 & 0.047 \\
\hline & $(0.020)$ & $(0.020)$ & $(0.20)^{* *}$ \\
\hline \multirow[t]{2}{*}{ ln_LTLIAB } & -0.031 & -0.015 & -0.019 \\
\hline & $(0.009)^{* * *}$ & $(0.010)$ & $(0.009)^{\star *}$ \\
\hline \multirow[t]{2}{*}{ ln_STLIAB } & -0.080 & 0.096 & -0.029 \\
\hline & $(0.023)^{* * *}$ & $(0.023)^{* * *}$ & $(0.026)$ \\
\hline \multirow[t]{2}{*}{ ln_ASSETS } & & & -0.172 \\
\hline & & & $(0.047)^{* * *}$ \\
\hline \multirow[t]{2}{*}{ LTLIAB/ASSETS } & & -0.442 & \\
\hline & & $(0.156)^{* * *}$ & \\
\hline \multirow[t]{2}{*}{ LTLIAB/TOTEQ } & -0.012 & & \\
\hline & $(0.025)$ & & \\
\hline R-sq within & 0.228 & 0.238 & 0.244 \\
\hline R-sq between & 0.021 & 0.025 & 0.007 \\
\hline R-sq overall & 0.057 & 0.063 & 0.027 \\
\hline
\end{tabular}

Note:Standard errors of parameters are reported in parentheses. ${ }^{\star}$ stands for significance at $10 \%,{ }^{\star \star}$ stands for significance at $5 \%,{ }^{* * *}$ stands for significance at $1 \%$.

In Table 8 for each model the estimation of Qadj parameters over time are omitted. For each model variables Y2011, Y2012, Y2013, Y2014 are included. They measure the mean change of Qadj value year to 2010 year which is used as the reference point. Parameters of used variables are: $-0.30,-0.29,-0.17$ and -0.26 respectively and are statistically significant. Thus, Qadj values in 2010 are the largest values on the analyzed period and lower in years 2011 and 2012 followed by a slight increase. Estimations of parameters confirm the tendencies over time documented in Table 3. 


\section{Conclusions and Future Study}

The effect of pyramidal structures on company performance remains a topic for ongoing debate (Almeida \& Wolfenzon, 2006; Bank \& Cheffins, 2010; Choi et al., 2021; Lin \& Yeh, 2020; Luo et al., 2021). Prior studies document the advantages and disadvantages of pyramidal business groups, addressing the view of efficient monitoring versus expropriation by the controlling shareholder. Our research adds to the existing corporate governance literature by presenting empirical evidence on the links between pyramidal ownership, the use of dual class shares and concentrated ownership and firm value in the environment of an underdeveloped capital market. Our study is based on unique, panel data on ownership, hand collected control structure and the market value of Polish companies listed on the Warsaw Stock Exchange in the years 2010-2014.

The results indicate that two selected ownership variables - the adoption of a pyramidal structure and the combined use of a pyramid, dual class shares and ownership concentration - are positively correlated with firm value. While we observe a negative link between the use of dual class shares and Q, the adoption of pyramids by blockholders remains statistically insignificant for company value.

In essence, our findings provide support for the efficient monitoring rationale of in the context of control leverage and the wedge between control and cash flow rights by pyramids. We argue that the controlling shareholder is not driven by the intention to expropriate minority shareholders. Interestingly, although dual class shares have a similar effect of control increase as pyramids, yet as prior literature reveals, they are used less frequently. Our results indicate that the simultaneous use of pyramids and dual class shares is negatively associated with Q suggesting that pyramids and dual class shares have different effects on company value.

These negative effects are offset by the combined adoption of a pyramid, dual class shares and ownership concentration which may align the interests of majority and minority shareholders. In conclusion, pyramidal ownership and the combination of pyramid, dual class shares and ownership concentration appear to function as efficient corporate governance mechanisms, in particular in the context of weaker institutional environment. Our study remains consistent with the most recent evidence showing positive effects of pyramids for improved coordination and potential for risk sharing between shareholders (Gama \& Bandeira-de-Mello, 2020) and in the case of financial distress (Buchuk et al., 2020).

Our results should nevertheless be treated with some measure of caution, due to some limitations in the sample and the focus on one country. These finding open up new opportunities for further research. We believe that studies on a number of countries, incorporating numerous ownership and firm characteristics, would be an interesting direction for future research and would help understanding of the impact that the complex structure of pyramids has on company performance and value.

\section{References}

Adams, R., \& Ferreira, D. (2008). One share-one vote: The empirical evidence. Review of Finance, 12(1), 51-91. https://doi.org/10.1093/rof/rfn003

Aldrighi, D.M., Postali, F.A., \& Diaz, M.D. (2018). Corporate governance and pyramidal ownership: The role of Novo Mercado. Revista Brasileira Finanças, 16(1), 5-38. https://doi.org/10.12660/rbfin.v16n1.2018.72020

Almeida, H., \& Wolfenzon, D. (2006). A theory of pyramidal ownership and family business groups. Journal of Finance, 61(6), 2637-2680. https://doi. org/10.1111/j.1540-6261.2006.01001.x

Almeida, H., Park, S.Y., \& Subrahmanyam, M., Wolfenzon, D. (2011). The structure and formation of business groups: Evidence from Korean chaebols. Journal of Financial Economics, 99(2), 447-475. https://doi.org/10.1016/j.jfineco.2010.08.017

Amoako-Adu, B., \& Smith B.F. (2001). Dual class firms: Capitalization, ownership structure and recapitalization back into single class. Journal of Banking and Finance, 25(6), 1083-1111. https:// doi.org/10.1016/S0378-4266(00)00107-2

Atavasov, V., Black, B., \& Ciccotello C. (2011). Law and tunneling. Journal of Corporation Law, 37, 1-49.

Attig, N, Fischer, K., \& Galdhoum J. (2004). On the determinants of pyramidal ownership: evidence on dilution of minority interests. EFA 2004 Maastricht Meetings Paper No. 4592.

Bae, K. H., \& Jeong, S. W. (2007). The value-relevance of earnings and book value, ownership structure and business groups affiliation: Evidence from Ko- 
rean business groups. Journal of Business, Finance and Accounting, 34(5-6), 740-766. https://doi.org/10.1111/ j.1468-5957.2007.02017.x

Baek, J.-S., Kang, J.-K., \& Park, K.-S. (2004). Corporate governance and firm value: Evidence from the Korean financial crisis. Journal of Financial Economics, 71(2), 265-313. https://doi.org/10.1016/S0304405X(03)00167-3

Bank, S., \& Cheffins, B. (2010). The corporate pyramid fable. Business History Review, 84(3), 435-458. https:// doi.org/10.1017/S0007680500002191

Bany-Ariffin, A., Nor F., \& McGowan, C. (2010). Pyramidal structure, firm capital structure exploitation and ultimate owners' dominance. International Review of Financial Analysis, 19(3), 151-164. https://doi. org/10.1016/j.irfa.2010.03.002

Bedo, Z., \& Acs, B. (2007). The impact of ownership concentration, and identity on company performance in the US and in Central and Eastern Europe. Baltic Journal of Management, 2(2), 125-139. https:/doi. org/10.1108/17465260710750955

Bena, J., \& Ortiz-Molina, H. (2013). Pyramidal ownership and the creation of new firms. Journal of Financial Economics, 108(3), 798-821. https://doi.org/10.1016/j. jineco.2013.01.009

Bennedsen, M., \& Nielsen, K. (2010). Incentive and entrenchment effects in European ownership. Journal of Banking and Finance, 34(9), 2212-2229. https:/doi. org/10.1016/j.jbankfin.2010.02.007

Boubaker, S. (2007). Ownership-control discrepancy and firm value: Evidence from France. Multinational Finance Journal, 11(3,4), 211-252. https:/doi. org/10.2139/ssrn.740756

Bozec, Y., Bozec, R., \& Dia, M. (2010). Overall governance, firm value and deviation from one share-one vote principle. International Journal of Managerial Finance, 6(4),305-328. https://doi. org/10.1108/17439131011074468

Brüderl, J. (2015). Applied panel data analysis using Stata, Panel Analysis, Ludwig-Maximilians Universität München.

Buchuk, D., Larrain, B., Prem, M., \& Infante F. (2020). How do internal capital markets work? Evidence from the great recession. Review of Finance, 24(4), 847-889. https://doi.org/10.1093/rof/rfz022

Buchuk, D., Larrain, F., Muñoz F., \& Urzúa F. (2014). The internal capital markets of business groups: Evidence from intra-group loans. Journal of Financial Economics, 112 (2), 190-212. https://doi.org/10.1016/j.jfineco.2014.01.003

Cameron, A., \& Trivedi, P. (2005). Microeconometrics. Methods and applications, Cambridge University Press.
Choi, D., Choi, S., Gam, J.K., \& Shin, H. (2021). R\&D investment decisions in business groups: Evidence from a natural experiment. Corporate Governance International Review, 1-25, https://doi. org/10.1111/corg.12407

Claessens, S., Diankov, S., \& Lang, H. (2000). The separation of ownership and control in East Asian corporation. Journal of Finance, 58(1-2), 81-112. https://doi.org/10.1016/S0304-405X(00)00067-2

Claessens, S., Diankov, S., Fan, J., \& Lang, H. (2002). Disentangling the incentive and entrenchment effects of large shareholdings. Journal of Finance, 57(6), 2741-2771. https://doi.org/10.1111/15406261.00511

Cornett, M., Marcus, A., \& Saunders, A. (2007). The impact of institutional ownership on corporate operating performance. Journal of Banking and Finance, 31(6), 1771-1794. https://doi.org/10.1016/j. jbankfin.2006.08.006

Cronqvist, H., \& Nilsson, M. (2003). Agency costs of controlling minority shareholders. Journal of Financial and Quantitative Analysis, 38(4), 695-719. https://doi.org/10.2307/4126740

De Angelo, H., \& De Angelo, L. (1985). Managerial ownership of voting rights: A study of public corporations with dual classes of common stock. Journal of Financial Economics, 14(1), 33-69. https://doi.org/10.1016/0304-405X(85)90043-1

Demsetz H., \& Lehn K. (1985). The structure of corporate ownership: Causes and consequences. Journal of Political Economy, 93(6), 1155-1177. https://doi. org/10.1086/261354

Djebali, R., \& Belanès, A. (2015). On the impact of family versus institutional blockholders on dividend policy. Journal of Applied Business Research, 31(4), 1329-1342. https://doi.org/10.19030/jabr. v31i4.9320

Espinoza-Méndez, Ch., Jara-Bertín, M., \& Maquiera C. (2018). The influence of family and pyramidal ownership on corporate diversification in Chile. The North American Journal of Economics and Finance, 43, 158-168. https://doi.org/10.1016/j. najef.2017.10.012

Faccio, M., \& Lang L. (2002). The ultimate ownership of Western European corporations. Journal of Financial Economics, 65(3), 365-395. https://doi. org/10.1016/S0304-405X(02)00146-0

Florackis, C., A. Kanas, \& Kostakis A. (2015). Dividend policy, managerial ownership and debt financing: A non-parametric perspective. European Journal of Operational Research, 214(3), 783-795. https:// doi.org/10.1016/j.ejor.2014.08.031 
Gama, M. A. B., \& Bandeira-de-Mello, R. (2021). The effect of affiliation structure on the performance of pyramidal business groups. Journal of Business Research, 124, 24-37. https://doi.org/10.1016/j. jbusres.2020.11.041

Gilson, R., \& Schwarz, A. (2013). Contracting about private benefits of control. Columbia Law and Economics Research Paper no. 436. https://law.stanford.edu/wp-content/uploads/sites/default/files/ publication/359494/doc/slspublic/ssrn-id2182781. $p d f$

Gonenc, H., Kan, O., \& Karadagli E. (2007). Business groups and internal capital market. Emerging Markets, Finance and Trade, 43(2), 63-81. https:// doi.org/10.2753/REE1540-496X430204

Han Kim, E., \& Kim, W. (2008). Changes in Korean corporate governance: A response to crisis. Journal of Applied Corporate Finance, 20(1), 47-58. https://doi.org/10.7312/chew14854-010

Hardi, P., \& Buti, K. (2012). Corporate governance variables: Lessons from a holistic approach to Central-Eastern European practice. Corporate Governance, 12(1), 101-117. https://doi. org/10.1108/14720701211191364

Holmén M., \& Högfeldt P. (2005). Pyramidal discounts: Tunneling or agency costs? Finance Working Paper, no. 73, European Corporate Governance Institute.

Holmén, M., \& Högfeldt, P. (2009). Pyramidal discounts: Tunneling or overinvestment? International Review of Finance, 9(1-2), 133-175. https:// doi.org/10.1111/j.1468-2443.2009.01088.x

Holmén, M., \& Nivorozhkin, E. (2007). The impact of family ownership and dual class shares on takeover risk. Applied Financial Economics, 17(10), 785804. https://doi.org/10.1080/09603100500461694

Hussain, H., Ali, A., Thaker H., \& Ali, M. (2019). Firm performance and family related directors: Empirical evidence from an emerging market. Contemporary Economics, 13(2), 187-204. https://doi. org/10.5709/ce.1897-9254.307

Jara-Bertin, M., López-Iturriaga, F., \& López-deForonda O. (2008). The contest to the control in European family firms: How other shareholders affect firm value. Corporate Governance: An International Review, 16(3), 146-159. https://doi. org/10.1111/j.1467-8683.2008.00677.x

Khanna, T., \& Palepu, K. (2000). Is group affiliation profitable in emerging markets? An analysis of diversified Indian business groups. Journal of Finance, 55(2), 867-891. https://doi. org/10.1111/0022-1082.00229
Khanna, T., \& Rivkin, J. (2001). Estimating the performance effects on business groups in emerging markets. Strategic Management Journal, 22(1), 45-74. https://doi.org/10.1002/10970266(200101)22:1<45::AID-SMJ147>3.0.CO;2-F

Koop, G. (2008). Introduction to Econometrics. Wiley \& Sons Ltd.

La Porta, R., Lopez-de-Silanes F., \& Shleifer, A. (1999). Corporate ownership around the world. Journal of Finance, 54(2), 471-517. https:/doi. org/10.1111/0022-1082.00115

Lemmon, M., \& Lins K. (2003). Ownership structure, corporate governance, and firm value: Evidence from the East Asian Financial crisis. Journal of Finance, 58(4), 1445-1468. https://doi. org/10.1111/1540-6261.00573

Lin, J. J., \& Yeh, Y-H. (2020). Internal capital markets, ownership structure, and investment efficiency: Evidence from Taiwanese business groups. Pacific-Basin Finance Journal, 60. https://doi. org/10.1016/j.pacfin.2020.101284

Luo, J.-H., Li, X., Wang, L. C., \& Liu, Y. (2021). Owner type, pyramidal structure and R\&D Investment in China's family firms. Asia Pacific Journal of Management, 38, 1085-1111. https://doi.org/10.1007/ s10490-019-09702-Z

Ly, T. T. H., \& Duc, N. K. (2018). Corporate governance, pyramid ownership, and firm value: Evidence from Vietnam. Journal of Asian Business and Economic Studies, 25(1), 85-102. https://doi. org/10.24311/jabes/2018.25.S01.4

Marchica, M., \& Mura, R. (2005). Direct and Ultimate Ownership structures in the UK: An intertemporal perspective over the last decade. Corporate Governance, 13(1), 26-45. https://doi.org/10.1111/ j.1467-8683.2005.00401.x

Masulis, R., Pham, P., \& Zein, J. (2011). Family business groups around the world: Financing advantages, control motivations, and organizational choices. Review of Financial Studies, 24, 35563600. https://doi.org/10.1093/rfs/hhr052

Maug, E. (1997). Boards of directors and capital structure: alternative forms of corporate restructuring. Journal of Corporate Finance, 3, 113-139. https:// doi.org/10.1016/S0929-1199(96)00010-7

Mindzak, J. \& Zeng, T. (2018). The impact of pyramid ownership on earnings management. Asian Review of Accounting, 26(2), 208-224. https://doi. org/10.1108/ARA-11-2016-0130

Morck, R. (2005). How to eliminate pyramidal business groups - the double taxation of inter-corporate dividends and other incisive uses of tax 
policy. Tax Policy and the Economy, 19, 135-179. https://doi.org/10.1086/tpe.19.20061898

Morck, R., Percy, M., Tian, G., \& Yeung B. (2005). the rise and fall of the widely held firm: A history of corporate ownership in Canada In R. Morck (Ed.) A history of corporate governance around the world: Family business groups to professional managers, University of Chicago Press, 65-148.

Nenova, T. (2003). The value of corporate voting rights and control: A cross-country analysis. Journal of Financial Economics, 68(3), 325-351. https://doi. org/10.1016/S0304-405X(03)00069-2

Perkins, S., Morck, R., \& Young, B. (2014). Innocents abroad: The hazards of international joint ventures with pyramidal group firms. Global Strategy Journal, 4(4), 310-330. https://doi.org/10.1002/gsj.1087

Pursey, P., Heugens, P., \& Zyglidopoulos, S. (2008). From social ties to embedded competencies: the case of business groups. Journal of Management \& Governance, 12(4), 325-341. https://doi.org/10.1007/ s10997-008-9064-7

Renneboog, L. (1999). Shareholdings concentration and pyramidal ownership structures in Belgium: Stylized facts, Onderzoeksrapport Nr. 9634, Department Toegepaste Econmische Wetenschappen, Katholieke Universiteit Leuven, 1-48.

Renneboog, L. (2000). Ownership, managerial control and the governance of companies listed on the Brussels stock exchange. Journal of banking \& finance, 24(12), 1959-1995. https://doi.org/10.1016/ S0378-4266(99)00128-4

Riyanto, Y., \& Toolsema, L. (2008). Tunneling and propping: A justification for pyramidal ownership. Journal of Banking and Finance, 32(10), 2178-2187. https://doi.org/10.1016/j.jbankfin.2007.12.044

Sánchez-Ballesta, J., \& García-Meca, E. (2007). A metaanalytic vision of the effect of ownership structure on firm performance. Corporate Governance: An International Review, 15(5), 879-892. https://doi. org/10.1111/j.1467-8683.2007.00604.x

Shah, M.H., Xiaob, Z., Abdullahc, Qureshd, S., \& Ahmad, M. (2020). Internal pyramid structure, contract enforcement, minority investor protection, and firms' performance: Evidence from emerging economies. Research in International Business and Finance, 52, https://doi.org/10.1016/j. ribaf.2019.101170

Shleifer, A., \& Vishny, R. (1997). A survey of corporate governance. Journal of Finance, 52, 737-783. https:// doi.org/10.1111/j.1540-6261.1997.tb04820.x

Smart, S.B., \& Zutter, C.J. (2003). Control as a motivation for underpricing: A comparison of dual and single-class IPOs. Journal of Financial Economics, 69(1), 85-110. https://doi.org/10.1016/S0304405X(03)00109-0

$\mathrm{Su}, \mathrm{K}$. (2015). The inner structure of pyramid and capital structure: Evidence from China. Economics: The Open-Access, Open-Assessment E-Journal 9. https:// doi.org/10.5018,economics-eJ.ournal.J.a.2015-14

Su, K., Wan, R., \& Song, W.Y. (2018). Pyramidal structure, risk-taking and firm valuel Evidence from Chinese local SOEs. Economics of Transition Volume, 26(3), 401-427. https://doi.org/10.1111/ ecot.12156

Su, Y., Xu, D., \& Phan, P. (2008). Principal-principal conflict in the governance of the Chinese public corporation. Management and Organization Review, 4(1), 17-38. https://doi.org/10.1111/j.17408784.2007.00090.x

Taylor, S., \& Whittred, G. 1998. Security design and the allocation of voting rights: Evidence from the Australian IPO market. Journal of Corporate Finance, $4(2), \quad 107-131 . \quad$ https://doi.org/10.1016/S09291199(97)00012-6

Villalonga, B., \& Amit, R. (2008). How are US family firms controlled? Review of Financial Studies, 22(8), 3047-3091. https://doi.org/10.1093/rfs/hhn080

Vintila, G., Gherghina S.C., \& Nedelescu M. (2014). The effects of ownership concentration and origin on listed firms' value. Empirical evidence from Romania. Romanian Journal of Economic Forecasting, 17(3), 51-71.

Wang, H.-D., Lin, Ch.-H., Cho, Ch.-Ch. (2020). The dark and bright sides of agency problems: Evidence from insider compensation of family pyramidal firms. Asia Pacific Management Review 25(3), 122 133.

Wooldrigde, J. 2000. Introductory Econometrics. A Modern Approach, South-Western College Publishing.

Young, M., Peng, M., Alstrom, D., Bruton G., \& Jiang, Y. (2008). Corporate governance in emerging economies: A review of the principal-principal perspective. Journal of Management Studies, 45(1), 196-220. https://doi.org/10.1111/j.1467-6486.2007.00752.x

Yurtoglu, B. (2003). Corporate governance and implications for minority shareholders in Turkey. Journal of Corporate Ownership and Control, 1, 72-86.

Zattoni, A. 1999. The structure of corporate groups: The Italian case. Corporate Governance, 7(1), 38-48. 